\title{
An icy past
}

\section{During several intervals in Earth's history, ice sheets expanded to cover the globe. These glaciations may be intricately linked to the evolution of life.}

The idea of a great glaciation covering the Earth from poles to tropics is not a new one. In 1837, Louis Agassiz argued for a single global glaciation, to much controversy ${ }^{1}$. However, by the midtwentieth century, glacial deposits were identified on most continents and, intriguingly, at tropical latitudes. Agassiz's preferred mechanism of divine wrath was soon replaced by more mundane causes, such as changes in orbital parameters or the Sun itself. Of course, many of these assumed global glaciations were later shown to be artefacts of continental drift ${ }^{1}$. In fact, all of the great glaciations of the past 500 million years were shown to be constrained to high latitudes. But multiple tectonic reconstructions showed that earlier glacial deposits, of the Palaeoproterozoic and the late Neoproterozoic, were indeed formed at low latitudes. These glaciations were therefore likely to be truly global or near-global, and have become known as Snowball Earth glaciations. We explore the causes and consequences of these Snowball Earth events in an accompanying web focus (http://www.nature.com/ngeo/focus/ snowball-earth/index.html)

Only one Snowball Earth glaciation is confirmed in the Palaeoproterozoic, roughly between 2.3 and 2.2 billion years ago. Comparatively little is known about this glaciation, but its cause may be the easiest to explain: this Snowball Earth follows the Great Oxidation Event, during which the rise of photosynthetic organisms pushed atmospheric oxygen concentrations from negligible amounts to low, but appreciable levels. The relatively faint young Sun was at this time countered, at least in part, by a methane greenhouse. The oxidation of atmospheric methane to other gases, including the (much less efficient) greenhouse gas carbon dioxide, would have lowered temperatures, allowing glaciation to take hold ${ }^{2}$.

Following the end of this glaciation, presumably resulting from the buildup of volcanic $\mathrm{CO}_{2}$ in the atmosphere, climate remained more or less stable for the next billion years. The next Snowball Earth glaciation, marking the start of the Cryogenian, arrived at a time of environmental upheaval. In the lead up to

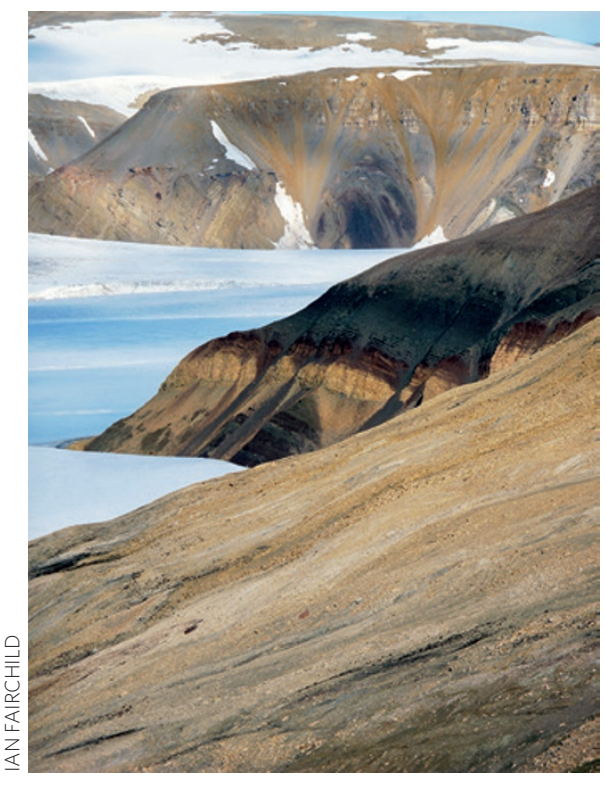

The rock record of a Snowball Earth glaciation.

at least two global glaciations beginning about 720 million years ago, carbon isotope excursions record large fluctuations in the carbon cycle, the marine redox structure shifted, and organisms with complex cells spread through the oceans ${ }^{3}$. During the two known Snowball Earth glaciations of the Cryogenian, the Sturtian and the Marinoan, ice sheets expanded into the tropics. Sea ice covered much of the oceans - exactly how much is a matter of debate - and may have varied between the two glaciations.

The causes of these snowball events are less clear. During the Neoproterozoic, vast volcanic eruptions emplaced swaths of basaltic rock throughout the continents, including some in the tropics. The rapid weathering of the fresh basalts in tropical conditions consumed atmospheric $\mathrm{CO}_{2}$. The break-up of the supercontinent Rodinia also enhanced weathering and run-off ${ }^{4}$, which further lowered atmospheric $\mathrm{CO}_{2}$ concentrations. However, it is unclear whether this level of $\mathrm{CO}_{2}$ sequestration was sufficient to tip the Earth into a snowball glaciation.

On page 659, Feulner and colleagues suggest that the expansion of life specifically algae - may have aided cooling prior to the Sturtian glaciation. Today, algae are substantial source of cloud condensation nuclei, which increase the reflectivity of clouds, and promote climate cooling. In their simulations, changes in the radiative forcing by clouds, along with atmospheric $\mathrm{CO}_{2}$ drawdown, are sufficient to initiate a snowball glaciation.

In comparison, it seems relatively easy to get out of a Snowball Earth glaciation. Under the ice sheets, volcanoes continue to emit $\mathrm{CO}_{2}$ and other greenhouse gases that build in the atmosphere and warm the Earth until a temperature threshold is reached, triggering deglaciation. On page 704 of this issue, Benn and colleagues suggest that this process might be more complex than previously thought. They identify a number of glacial deposits that show an active retreat and expansion of ice sheets at the end of the Marinoan glaciation. Using a climate model, they show that when a certain threshold of atmospheric $\mathrm{CO}_{2}$ concentration is reached, the snowball ice sheets transition from a fixed and stable ice sheet to one capable of responding to orbital variations (much like the ice sheets of the Pleistocene). This finding nicely reconciles conflicting evidence for stable and fluctuating ice sheets found in the Cryogenian rock record.

Out of 4.5 billion years of Earth history, Snowball Earth conditions are known to have existed for a mere several hundred million years. The conditions needed for ice sheets to encase the globe must thus be extraordinary. Intriguingly, these conditions are increasingly appearing to be linked to changes in life - the proliferation of photosynthesis in the case of the Palaeoproterozoic Snowball and the expansion of algae in the Neoproterozoic glaciations. It is increasingly clear that life has had a profound influence on climate and the chemistry of the Earth's surface since its earliest advent; similar impacts continue to this day.

\section{References}

1. Eyles, N. \& Januszczak, N. Earth Sci. Rev. 65, 1-73 (2004)

2. Kopp, R. E., Kirschvink, J. L., Hilburn, I. A. \& Nash, C. Z. Proc. Natl Acad. Sci. USA 102, 11131-11136 (2005)

3. Johnston, D. T. et al. Earth Planet. Sci. Lett. 290, 64-73 (2010).

4. Donnadieu, Y., Godderis, Y., Ramstein, G., Nedelec, A. \& Meert, J. Nature 428, 303-306 (2004). 